\title{
The Challenge of the Society of the Future: Building Relationships through Human/Nature Design
}

\author{
Simona Totaforti * \\ Associate Professor of Urban Sociology, University in Reggio Calabria, Italy
}

Submission: November 24, 2018; Published: December 03, 2018

"Corresponding author: Simona Totaforti, Associate Professor of Urban Sociology, University in Reggio Calabria, Italy

\begin{abstract}
The built environment can encourage or limit and restrict the behaviour of individuals within that space. A lived-in space is one where the experiences of inhabitants, their interactions and their representations are condensed together. That does not only entail defining a theoretical point of view, but also, and more importantly, reflecting on the criteria for innovation projects and being able to respond to the challenges that the future poses for society. In this respect, Human/nature design (HND) represents a change in perspective: this is because it is based on reestablishing a connection between people and nature (with its frameworks, shapes and materials), which leads to improved psycho-physical well-being, and because the individual becomes a central player within the space and moulds it according to their wants and needs.
\end{abstract}

Keywords: Urban studies; Nature; Design; Space; Relationships

\section{Mini Review}

The built environment can encourage or limit and render unsafe the behaviour of individuals within that space. The space that surrounds us can be imagined as a musical score, one that individuals may not realise they are constantly immersed in. The music that is played from that score conveys messages that shape our emotions and perceptions, and which allow us to know what can be expected and how we can act within the environment. This is a complex process that results from a continuous decoding of information and, as Lynch claimed, a mapping of the space that defines the city's features as they are perceived by its inhabitants.

However, when the built environment is completely out of synch with the needs of the people, the message produced is hostile. The people, as a result, do not feel comfortable and feel that they are in environments in which they have no control over the space-time rules that regulate activities. To put it simply, the space does not communicate a sense of order and harmony, but rather that the well-being of individuals is of secondary importance. In order to understand to what extent this misalignment has spread throughout contemporary cities, one need only think of work spaces, housing, public spaces, hospitals and the feelings and emotions that these places evoke. These are often spaces that make us less happy and less calm, rather than boosting our wellbeing. How can this situation be changed? This is the challenge for the society of the future: to plan or breathe new life into cities according to the needs of the people.

Clearly this is not an easy task, particularly for places with a heavier emotional load, such as hospitals and, more generally, places for treatment and healing. Urban planning is often completely disconnected from the impact that it generates on the lives of the people who will inhabit those spaces, or who will often only visit them for a short period of time. These are often spaces that can deprive people of their dignity, places that are distant from the reality of the people, from the needs of the community and from the social impact they can have.

There is no new style, one which starts with the knowledge that such planning can restore a person's dignity. Such planning can make people feel valued, respected, visible and, above all, it can determine measurable physical well-being. Or, at least, so it seems judging from the planning outcome produced not only in Italy, but also worldwide. The most interesting planning outlook today is one that defines activities that can overcome the distance that has been created between people and their environment, by reconnecting us with our most profound possession: nature. It's all about relationships.

In fact, design can address products, processes and relationships (between people within the space, between people and the space itself or between people and the objects found within the space). Upon closer inspection, it is from our experience of nature that design can derive the principles for planning and developing a harmonious human built environment. The central principles of Human/Nature Design focus on the development and well-being of individuals and communities, and on the construction of alternative models that can give people a voice and respond to their needs.

What is crucial here is that design pays close attention to the rights of the citizens in contemporary cities (even when, for 
example, they happen to be patients because they find themselves in a particularly fragile or stressful moment in their lives) and that it adopts an approach that is interdisciplinary, participative, participatory and reflective. Above all, it is a design that can bring experiences of nature into contemporary urban projects. Today, the city is a central subject in the field of social studies and represents the essential challenge facing the future of our society. We are compelled to respond to this challenge with a design that not only "envisions" our cities for their aesthetic value, but also aims to define processes and models that can create a fairer, more inclusive, cohesive and sustainable society.

Indeed, in this respect, it is interesting to highlight that HND represents a step in the right direction when compared to the simple concept of sustainability. In an intriguing essay published in 2010, entitled The Rhetoric of Sustainability: Perversity, Futility, Jeopardy? Meg Holden makes use of the classifications for reactions to social change proposed by Hirschman in order to understand the failure of the approach to sustainable development $[1,2]$.

In more general terms, we can say that the concept of sustainability, as it refers to a predominantly ecological/economic model, has, over the years, been limited to defining actions aimed at not compromising or causing further damage to the environment that surrounds us and provides us with a home. A constructive step, no matter how small, was however necessary. More precisely, HND is reminiscent of the concept of restorative design: the idea of not simply preventing further damage to the environment around us, but rather of planning actions to make it a better place for us all. This approach builds relationships and, in order to do so, it listens to those people who pass through and live within the spaces every day $[3,4]$.

The primary objectives of an HND-based project are certainly those that restore quality and functionality to these places, as well as dignity to those who pass through them, work in them or spend some time there. The project also becomes the result of a participatory task and the principle of community (which is too often neglected today in favour of more economic-based models), which is inclusive and aims to build new relationship networks or reinforce existing ones. The achievement of these objectives is fostered not only by the method and the approach on which HND is based, but also by the presence of natural elements in the project.

The relationship between people and nature is innate and has a profound impact on their health and well-being. When nature is introduced into the built environment - whether directly or through shapes, materials and patterns - it produces benefits in physical, mental and behavioural terms [4]. Benefits include increased comfort and satisfaction [5], lower stress levels [6], greater concentration $[7,8]$, better social interaction, reduced hostility and aggression [4].

International studies demonstrate the scientific basis for this design, which revitalizes the relationship between people and nature and the consequent environmental, social and economic benefits. Environments designed in accordance with this philosophy aim to recover an awareness of the therapeutic value of nature, the sun and natural ventilation. As a result, a design model capable of relating spatial organization to actions that stimulate the senses is established and, more generally, one that can tune in on the needs of individuals and encourage the design of the cities they want $[9,10]$. This is bound to result in improved quality of life, because people are carriers of specific and unique needs, emotions and necessities.

\section{References}

1. Holden, M (2010) The Rhetoric of Sustainability: Perversity, Futility, Jeopardy? Sustainability 2(2): 645-659.

2. Hirschman, AO (1991) The Rhetoric of Reaction: Perversity, Futility, Jeopardy. Belknap Press: Cambridge, MA, USA.

3. Kellert SR, Heerwagen JH, Mador ML (2008) Biophilic design. The theory, science and practice of bringing buildings to life, Wiley, New Jersey.

4. Kellert, S, Calabrese, E (2015) The practice of biophilic design.

5. Biederman I, Vessel EA (2006) Perceptual pleasure and the brain. A novel theory explains why the brain craves information and seeks it through the senses. American Scientist 94(3): 247-253.

6. Park, Tsunetsugu, Kasetani, Morikawa, Kagawa, et al. (2009) Physiological effects of forest recreation in a young conifer forest in Hinokage Town, Japan. Silva Fennica 43(2): 291-301.

7. Heschong, L (2003) Windows and offices: A study of office worker performance and the indoor environment. California Energy Commission: Pacific Gas and Electric Company. Fair Oaks, California.

8. Lee, Williams, Sargent, Williams, Johnson (2015) Forty-second green roof views sustain attention: The role of micro-breaks in attention restoration. Journal of Environmental Psychology 42: 182-189.

9. Totaforti S (2018) Applying the benefits of biophilic theory to hospital design. City Territory Architecture 5: 1.

10. Terrapin Bright Green (2012) The economics of biophilia. NY: Terrapin Bright Green LLC, New York. 
This work is licensed under Creative Commons Attribution 4.0 License DOI: 10.19080/ASM.2018.02.555588

\section{Your next submission with Juniper Publishers} will reach you the below assets

- Quality Editorial service

- Swift Peer Review

- Reprints availability

- E-prints Service

- Manuscript Podcast for convenient understanding

- Global attainment for your research

- Manuscript accessibility in different formats

( Pdf, E-pub, Full Text, Audio)

- Unceasing customer service

Track the below URL for one-step submission https://juniperpublishers.com/online-submission.php 